\title{
A parvicapsulid (Myxozoa) infecting Sprattus sprattus and Clupea harengus (Clupeidae) in the Northeast Atlantic uses Hydroides norvegicus (Serpulidae) as invertebrate host
}

\author{
Marianne Køie $^{1}$, Egil Karlsbakk ${ }^{2,3}$, Ann-Cathrine Bårdsgjære Einen ${ }^{2}$ and Are Nylund ${ }^{3}$ \\ ${ }^{1}$ Marine Biological Laboratory, University of Copenhagen, Helsingør, Denmark; \\ ${ }^{2}$ Institute of Marine Research, Bergen, Norway; \\ ${ }^{3}$ Department of Biology, University of Bergen, Norway
}

\begin{abstract}
A myxosporean producing actinospores of the tetractinomyxon type in Hydroides norvegicus Gunnerus (Serpulidae) in Denmark was identified as a member of the family Parvicapsulidae based on small-subunit ribosomal DNA (SSU rDNA) sequences. Myxosporean samples from various Danish and Norwegian marine fishes were examined with primers that detect the novel myxosporean. Sprattus sprattus (Linnaeus) and Clupea harengus Linnaeus (Teleostei, Clupeidae) were found to be infected. The sequences of this parvicapsulid from these hosts were consistently slightly different ( $0.8 \%$ divergence), but both these genotypes were found in H. norvegicus. Disporic trophozoites and minute spores of a novel myxosporean type were observed in the renal tubules of some of the hosts found infected through PCR. The spores appear most similar to those of species of Gadimyxa Køie, Karlsbakk et Nylund, 2007, but are much smaller. The actinospores of the tetractinomyxon type from H. norvegicus have been described previously. In GenBank, the SSU rDNA sequences of Parvicapsulidae gen. sp. show highest identity (82\%) with Parvicapsula minibicornis Kent, Whitaker et Dawe, 1997 infecting salmonids (Oncorhynchus spp.) in fresh water in the western North America. A phylogenetic analysis places P. minibicornis and Parvicapsulidae gen. sp. in a sister clade to the other parvicapsulids (Parvicapsula spp. and Gadimyxa spp.).
\end{abstract}

Keywords: Myxozoa, Parvicapsulidae, Clupea harengus, Sprattus sprattus, actinospores, life cycle, Denmark, Norway

Many two-host life cycles of freshwater myxozoans are known (see Yokoyama et al. 2012), but only five marine life cycles have been elucidated (Køie et al. 2004, 2007, 2008, Rangel et al. 2009, Karlsbakk and Køie 2012). These represent members of the genera Ceratomyxa Thélohan, 1892; Ellipsomyxa Køie, 2003; Gadimyxa Køie, Karlsbakk et Nylund, 2007; and Sigmomyxa Karlsbakk et Køie, 2012, all belonging to the marine clade of Myxosporea (Fiala 2006). These develop actinospores of the tetractinomyxon type in their polychaete hosts. Recently, a markedly different actinosporean type, unicapsulactinomyxon, was discovered in the polychaete Diopatra neapolitana Delle Chiaje from Portugal (Rangel et al. 2011). Based on its SSU rDNA sequence, this unidentified myxosporean is most closely related to Enteromyxum spp., which also belong to the marine clade of Myxosporea.

In this study we present evidence suggesting that the marine polychaete Hydroides norvegicus Gunnerus (Polychaeta, Serpulidae) from the northern Øresund, Denmark, is the invertebrate host of a novel parvicapsulid parasite infecting the urinary system of sprat Sprattus sprattus (Linnaeus) and Atlantic herring Clupea harengus Linnaeus.

\section{MATERIALS AND METHODS}

From Denmark, 200 specimens of sprat Sprattus sprattus (10-15 cm in total length) and 100 specimens of the Atlantic herring Clupea harengus (15-20 cm in length) were examined. The fishes were trawled in the northern Øresund $\left(55^{\circ} 58^{\prime} \mathrm{N}\right.$, $\left.12^{\circ} 40^{\prime} \mathrm{E}\right)$ at $15-20 \mathrm{~m}$, September-December 2007 and 2008. From Norway, samples were taken from sprat from Hardanger $\left(60^{\circ} 24^{\prime} 56^{\prime \prime} \mathrm{N}, 6^{\circ} 31^{\prime} 29 " \mathrm{E}\right)$, western Norway $(\mathrm{N}=2 ; 9.5-12.5 \mathrm{~cm}$ in length) in August 2008 and from Vefsnfjorden, northern Norway (six sprat 6.4-8.2 cm long; two herring $12.8-13.1 \mathrm{~cm}$ long) $\left(65^{\circ} 56^{\prime} 36^{\prime \prime} \mathrm{N}, 12^{\circ} 42^{\prime} 12^{\prime \prime} \mathrm{E}\right)$ in November 2011 . The latter specimens of the two clupeids were caught in the same trawl haul. Some fish were examined fresh, but most were frozen immediately upon capture.

Kidney samples for DNA were stored in 96\% ethanol. Squash preparations were made from various parts of the kidney and examined at $1000 \times$ magnification for myxosporean spores and trophozoites. The Vefsnfjorden samples could not be examined at high magnification due to the movement and vibrations in the research vessel (RV 'Helmer Hansen') at sea. Myxospore

Address for correspondence: E. Karlsbakk, Institute of Marine Research, P.O. Box 1870, Nordnes, N-5817 Bergen, Norway. Phone: +4755236362 ; Fax: +47 552385 31; E-mail: egil.karlsbakk@imr.no 
Table 1. Variable and ambiguous positions in partial SSU rDNA sequences of Parvicapsulidae gen. sp. from sprat, herring and Hydroides norvegicus. Positions given with reference to JX136956.

\begin{tabular}{|c|c|c|c|c|c|c|c|c|c|c|c|c|c|c|c|c|c|c|}
\hline \multirow{2}{*}{$\begin{array}{l}\text { Sequence } \\
\text { isolate }\end{array}$} & \multirow{2}{*}{$\begin{array}{l}\text { GenBank } \\
\text { Accession No. }\end{array}$} & \multirow[t]{2}{*}{ Host } & \multicolumn{16}{|c|}{ Geno- Positions } \\
\hline & & & & 320 & 472 & 480 & $505-6$ & 508 & 519 & $535-6$ & 547 & $575-6$ & 1175 & 1184 & 1208 & 1218 & 1231 & 1590 \\
\hline HyAug & HQ588150 & Hydroides & B & $\mathrm{C}$ & G & $\mathrm{T}$ & TY & $\mathrm{C}$ & A & GG & $\mathrm{C}$ & $\mathrm{CC}$ & G & A & $\mathrm{T}$ & $\mathrm{T}$ & A & $\mathrm{T}$ \\
\hline HySep & HQ588151 & Hydroides & B & $\mathrm{C}$ & G & $\mathrm{T}$ & TY & $\mathrm{C}$ & A & GG & $\mathrm{C}$ & $\mathrm{CC}$ & G & A & $\mathrm{T}$ & $\mathrm{T}$ & A & $\mathrm{T}$ \\
\hline OrSpr & HQ588153 & Sprat & B & $\mathrm{C}$ & G & $\mathrm{T}$ & TY & $\mathrm{C}$ & A & GG & $\mathrm{C}$ & $\mathrm{CY}$ & K & A & $\mathrm{T}$ & K & A & $\mathrm{T}$ \\
\hline OrSprNy & HQ588154 & Sprat & B & $\mathrm{C}$ & G & $\mathrm{T}$ & TY & $\mathrm{C}$ & A & GG & $\mathrm{C}$ & $\mathrm{CC}$ & G & A & $\mathrm{T}$ & $\mathrm{T}$ & A & $\mathrm{T}$ \\
\hline Spr-2 & JX136962 & Sprat & B & $\mathrm{C}$ & G & $\mathrm{T}$ & TY & $\mathrm{C}$ & A & GG & $\mathrm{C}$ & $\mathrm{CC}$ & $\mathrm{T}$ & A & $\mathrm{T}$ & $\mathrm{K}$ & A & $\mathrm{T}$ \\
\hline Bri-1 & JX136955 & Sprat & B & $\mathrm{C}$ & G & $\mathrm{T}$ & TY & $\mathrm{C}$ & A & GG & $\mathrm{C}$ & $\mathrm{CC}$ & $\mathrm{T}$ & A & $\mathrm{T}$ & G & A & $\mathrm{T}$ \\
\hline Bri-2 & JX136956 & Sprat & B & $\mathrm{C}$ & G & $\mathrm{T}$ & TY & $\mathrm{C}$ & A & GG & $\mathrm{C}$ & $\mathrm{CY}$ & $\mathrm{T}$ & A & $\mathrm{T}$ & G & A & $\mathrm{T}$ \\
\hline Bri-3 & JX136957 & Sprat & B & $\mathrm{C}$ & G & $\mathrm{T}$ & $\mathrm{TC}$ & $\mathrm{C}$ & A & GG & $\mathrm{C}$ & $\mathrm{CC}$ & $\mathrm{K}$ & A & $\mathrm{T}$ & $\mathrm{K}$ & A & $\mathrm{T}$ \\
\hline Bri-4 & JX136958 & Sprat & B & $\mathrm{C}$ & G & $\mathrm{T}$ & $\mathrm{TC}$ & $\mathrm{C}$ & A & GG & $\mathrm{C}$ & $\mathrm{CC}$ & K & A & $\mathrm{T}$ & G & A & ou \\
\hline Bri-5 & JX136959 & Sprat & B & $\mathrm{C}$ & G & $\mathrm{T}$ & TY & $\mathrm{C}$ & A & GG & $\mathrm{C}$ & $\mathrm{CC}$ & K & A & $\mathrm{T}$ & K & A & $\mathrm{T}$ \\
\hline Bri-6 & JX136960 & Sprat & B & $\mathrm{C}$ & G & $\mathrm{T}$ & TT & $\mathrm{C}$ & A & GG & $\mathrm{C}$ & $\mathrm{CY}$ & K & A & $\mathrm{T}$ & $\mathrm{K}$ & A & $\mathrm{T}$ \\
\hline BriK-2 & JX136961 & Sprat & B & $\mathrm{C}$ & G & $\mathrm{T}$ & TY & $\mathrm{C}$ & A & GG & $\mathrm{C}$ & $\mathrm{CC}$ & $\mathrm{T}$ & A & $\mathrm{T}$ & G & A & ou \\
\hline Нy07 & HQ588152.2 & Hydroides & $\mathrm{B}+\mathrm{S}$ & $\mathrm{Y}$ & $\mathrm{R}$ & $\mathrm{Y}$ & WY & $\mathrm{C}$ & W & RK & Y & YC & K & $\mathrm{R}$ & Y & D & $\mathrm{R}$ & $\mathrm{Y}$ \\
\hline Hy1911 & HQ588149 & Hydroides & $\mathrm{S}$ & $\mathrm{T}$ & A & $\mathrm{C}$ & AT & $\mathrm{C}$ & W & AT & $\mathrm{T}$ & $\mathrm{TC}$ & $\mathrm{T}$ & G & $\mathrm{C}$ & A & G & $\mathrm{C}$ \\
\hline Mu-1 & JX136963 & Herring & S & $\mathrm{T}$ & A & $\mathrm{C}$ & AT & $\mathrm{C}$ & W & AT & $\mathrm{T}$ & $\mathrm{TC}$ & $\mathrm{T}$ & G & $\mathrm{C}$ & A & G & $\mathrm{C}$ \\
\hline Mu-2 & JX136964 & Herring & S & $\mathrm{T}$ & A & $\mathrm{C}$ & AT & $\mathrm{C}$ & W & AT & $\mathrm{T}$ & $\mathrm{TC}$ & $\mathrm{T}$ & G & $\mathrm{C}$ & A & $\mathrm{R}$ & $\mathrm{C}$ \\
\hline Clm-3 & JX136965 & Herring & S & $\mathrm{T}$ & A & $\mathrm{C}$ & AT & A & $\mathrm{T}$ & AT & $\mathrm{T}$ & $\mathrm{TC}$ & ou* & ou & ou & ou & ou & ou \\
\hline
\end{tabular}

*ou = outside. Additional ambiguous positions: $\mathrm{Y}$ at position 516 in Bri-6 only, $\mathrm{Y}$ at position 605 in Hy1911 and Mu-1, $\mathrm{Y}$ at position 1164 in Mu-1 and $\mathrm{Mu}-2$

measurements are based on six specimens from sprat and four specimens from herring, all from Denmark. Since the rare and small myxospores were not found in stained smears, micrographs of the myxospores are deposited in the Zoological Museum, Copenhagen, Denmark, Catalog No ZMUC-MYX-005 (photo-vouchers).

Specimens of Hydroides norvegicus were collected on their common substrate, the bivalve Aequipecten opercularis (Linnaeus). The bivalves were dredged in the northern Øresund at $25 \mathrm{~m}$, throughout the years 2001-2008. Some polychaetes were examined immediately upon capture; others were kept in aquaria provided with aerated, filtered seawater from a recirculation water system $\left(30 \% \mathrm{~S}, 10^{\circ} \mathrm{C}\right)$.

DNA was extracted from kidney pieces or pieces of actinospore-infected $H$. norvegicus using the DNeasy ${ }^{\circledR}$ Tissue Kit protocol for animal tissues (Qiagen, Hilden, Germany). The polymerase chain reaction (PCR) primers used to obtain partial small-subunit (SSU) ribosomal RNA gene (rDNA) sequences were MarF1/RosR2 (annealing temperature $56^{\circ} \mathrm{C}$ ), MyxF2/Myxgen4R $\left(57^{\circ} \mathrm{C}\right.$ ) (see Køie et al. 2008). Two sequences were slightly extended at the $5^{\prime}$ end using the primers Ecf (see Nylund et al. 2005) and HydrR $4\left(57^{\circ} \mathrm{C}\right)$. The primer pair HydrF2/Hydr-R4 $\left(54^{\circ} \mathrm{C}\right)$ was designed from the partial SSU rDNA sequence of the myxosporean infecting $H$. norvegicus and used for the examination of kidney pieces of various marine fishes for infections with the parasite. These primers have sequences 5'-ACTAAACTGCCTGTCGGTTAAG-3' and 5'-CCCACAACCAGAACACTTACA-3' respectively, and amplify a 267 bp product.

The PCR amplifications were performed in a total volume of $50 \mu \mathrm{l}$ using $2 \mu \mathrm{l}$ of template DNA and a reaction mixture consisting of $10-\mu 15 \times$ PCR buffer, $3 \mu 125 \mathrm{mM} \mathrm{MgCl}_{2}, 5 \mu 110 \mathrm{mM}$ dNTP, $2 \mu \mathrm{l}(10 \mathrm{mM})$ of the reverse and forward primers, $2 \mathrm{U}$ of

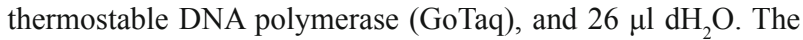
PCR conditions were as previously described (Køie et al. 2008). The PCR products were cleaned with ExoSAP-IT ${ }^{\circ}$ (Affymetrix Inc.) and then sequenced using the BigDye (3.1) Terminator Se- quencing kit. The sequencing was done using the amplification primers.

The sequence data were assembled with the Vector NTI Advance $^{\mathrm{TM}} 11$ software (Invitrogen Corp., Carlsbad, CA), and GenBank searches were done with BLAST (2.0). Alignments were obtained with Clustal W (AlignX, Vector NTI). Ambiguous signals occurred in the SSU rDNA sequences. These were registered if the secondary peak was consistently present in multiple reads and showed half or more of the signal of the major signal at that position.

The phylogenetic relationship between Parvicapsulidae gen. sp. and related Myxosporea was examined using Maximum Likelihood (ML) (MEGA 5; 500 bootstrap replicates) (Tamura et al. 2011) and Bayesian inference (BI) (MrBayes 3.1.2; $1 \times 10^{6}$ generations, every $100^{\text {th }}$ tree saved) (Ronquist and Huelsenbeck 2003). Sequences were aligned using AlignX, and manually edited in Genedoc. Hypervariable or ambiguous regions were deleted in order to achieve comparison of homologous positions. In the sequence of Sinuolinea sp. (GenBank accession number AF378346) the first $450 \mathrm{bp}$ were removed (see Holzer et al. 2010). The best model (AICc) of nucleotide substitution was GTR I $+\Gamma$ according to both MEGA5 and jModelTest (0.1.1). Ceratomyxa spp. were selected as outgroup based on previous studies (Fiala 2006, Bartošová et al. 2011). Trees with the same topology were obtained with MEGA5 and MrBayes.

The possible association of parasite genotype with fish host species was examined with the Fisher exact test using the Statistica 10 software (StatSoft, Tulsa, USA).

\section{RESULTS}

\section{SSU rDNA sequences}

Myxosporean partial SSU rDNA sequences were first obtained from tetractinomyxon-infected Hydroides norvegicus collected in January 2002 (sequence isolate 
Hy1911), and again from three worms collected in August (HyAug) and September 2007 (Hy07 and HySep). Two slightly different sequences (genotypes) were obtained, designated as type $\mathrm{B}$ and $\mathrm{S}$, differing at 12 sites $(99.2 \%$ identity, 1531 sites compared). In addition, ambiguous signals occurred at five sites (positions 506, 516, 576, 1175,1218 ) in the type B but not in our type $\mathrm{S}$ sequences, and at four sites (positions 519, 605, 1164,1231 ) in the type $\mathrm{S}$ sequences but not observed in those of type B (Table 1). Isolates HySep and HyAug represented type B, and Hy1911 type S. A fourth sequence from an infected $H$. norvegicus (Hy07) showed ambiguous signals at all the 12 sites used to distinguish the types B and S (a mixed $\mathrm{B}$ and $\mathrm{S}$ signal) (Table 1).

In fishes, a type B sequence was first obtained from a kidney sample of a sprat (sequence isolate OrSpr) collected in northern Øresund in November 2007, and later verified by sequencing from a second kidney sample obtained from the same fish (whole fish stored at $-20^{\circ} \mathrm{C}$ ). This fish was infected with minute myxospores (described below) in the kidney. Sequences from two additional sprat from Denmark infected with the same type minute myxospores were subsequently obtained (isolates OrSprNy, BriK-2). Additional type B sequences were obtained from: (i) a sprat from Hardanger (western Norway) examined because it had myxosporean trophozoites in the Bowman's space of renal corpuscles (isolate Spr-2) and (ii) from 6 kidney samples of sprat collected in Vefsnfjorden, northern Norway (isolates Bri-1 to Bri-6).

A type $\mathrm{S}$ sequence was first obtained from a herring infected with the minute type myxospores (isolate Clm-3). A second herring infected with the minute type myxospores was also PCR positive. Subsequently type $\mathrm{S}$ sequences were obtained from kidney samples of two juvenile herring from northern Norway (Mu-1 and $\mathrm{Mu}-2$ ).

\section{Phylogenetic affinities}

The sequences of Parvicapsulidae gen. sp. showed highest similarity with sequences of Parvicapsula minibicornis Kent, Whitaker et Dawe, 1997 in BLAST searches, and sequence comparisons show 82 and $88 \%$ identity with and without gaps, respectively. Fig. 1 shows the phylogenetic position of Parvicapsulidae gen. sp. among other parvicapsulids and selected members of the marine clade of Myxosporea. Parvicapsulidae gen. sp. is placed in a well supported clade together with $P$. minibicornis, Parvicapsula sp. genotype X and Sphaerospora testicularis. This clade represents a sister group to the other parvicapsulids (Fig. 1).

\section{Morphology of myxospores}

Fig. 2

No morphological differences were apparent between myxospores from sprat and herring. In total, only 30 myxospores were found in the two herring and three

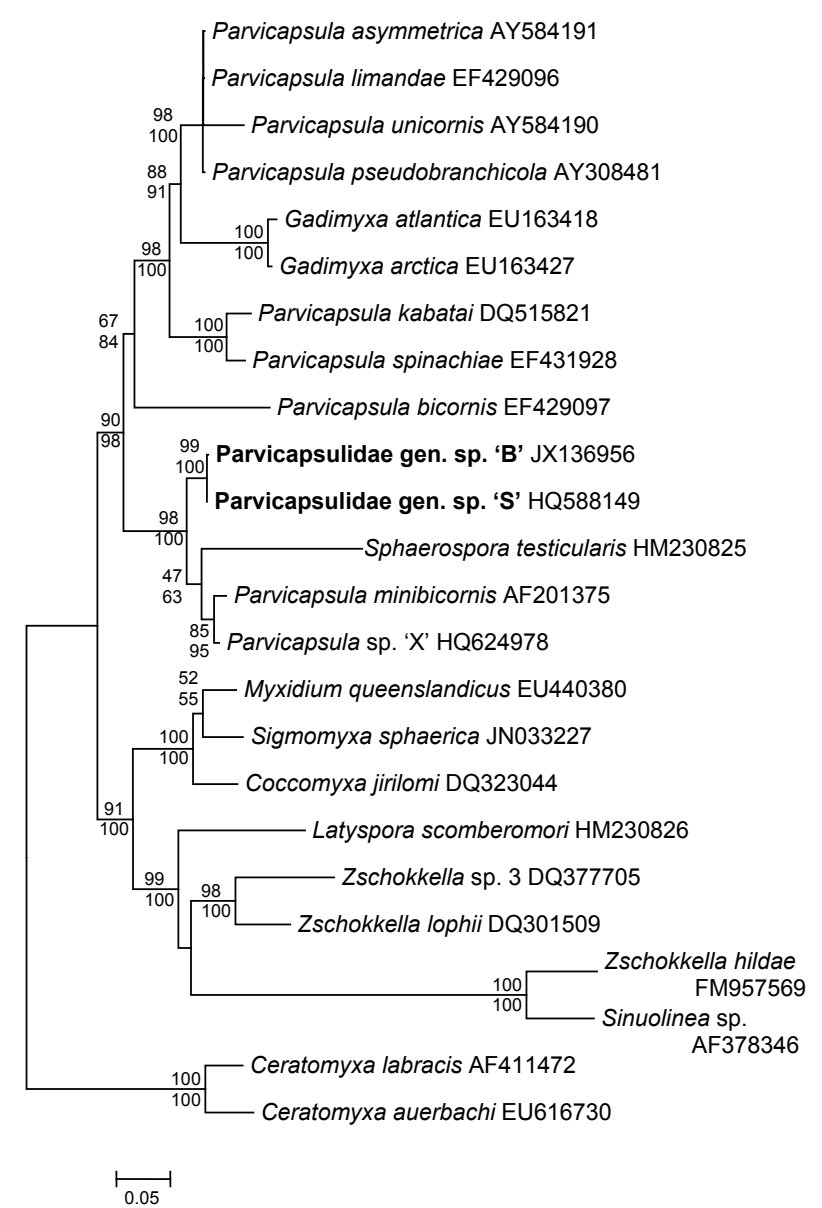

Fig. 1. Phylogenetic position of Parvicapsulidae gen. sp. as inferred from SSU rDNA data by using the maximum likelihood method (MEGA 5) $(\ln L=-7713.26)$. The analysis involved 24 nucleotide sequences and 1024 positions. Nodal supports $(\%)$ are indicated for ML (upper) and BI (lower, posterior probabilities), unless both were $<50 \%$.
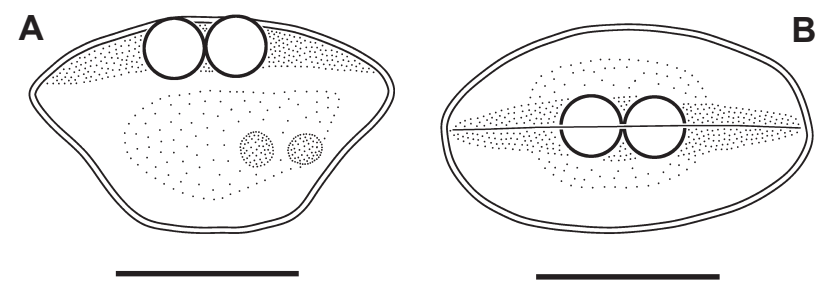

Fig. 2. Myxospores of Parvicapsulidae gen. sp. A - frontal view; B - apical view. Scale bar $=2 \mu \mathrm{m}$.

sprat. The description (measurements are in micrometres, $\mathrm{N}=10$ ) is based on myxospores from both hosts.

Spores ovoid in valvular view, wider than long; anterior end flattened, posterior more or less semicircular. Spores elliptical in apical view and bilaterally symmetrical along an inconspicuous sutural line. Two spherical polar capsules close to each other, in middle of most flattened side of spore. Spores smooth and thin-walled. Anterior end 


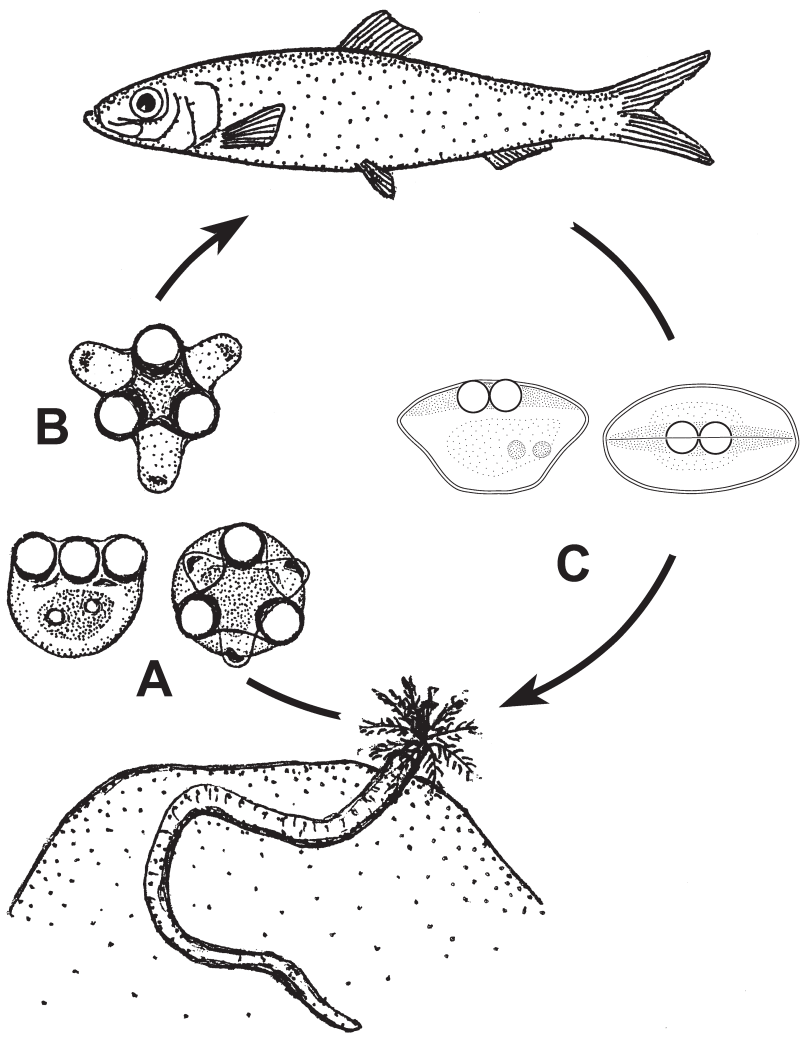

Fig. 3. Schematic illustration of the life cycle of Parvicapsulidae gen. sp. The polychaete Hydroides norvegicus (below) acts as the invertebrate host. The Atlantic herring, Clupea harengus, and sprat, Sprattus sprattus (above), act as the fish hosts. A-recently released actinospores; $\mathbf{B}$ - actinospore with slightly inflated epispores; $\mathbf{C}$ - myxospores, frontal and sutural views. Not to scale.

of spore slightly convex in valvular view; posterior side slightly angular. Spores 2.3-2.8 long, 4.0-4.4 wide and 2.3-2.6 thick. Polar capsules $0.6-0.7$ in diameter. A thickening follows inconspicuous sutural line and attenuates close to slightly pointed ends of spore. Number of coils of polar filament unknown (coils not visible).

Fig. 3 shows a schematic diagram of the proposed life cycle of the parvicapsulid.

\section{DISCUSSION}

Partial SSU rDNA sequences of the myxosporean producing tetractinomyxon actinospores in the polychaete Hydroides norvegicus (see Køie 2002) were throughout several years compared with sequences of myxosporeans from potential fish hosts. A myxosporean sequence from a kidney sample from a sprat infected with Ortholinea orientalis (Shul'man et Shul'man-Albova, 1953) matched the sequences from the actinospores. However, we were unable to obtain the sequence from the actinospores in $H$. norvegicus in several $O$. orientalis - infected herring. Another and completely unrelated myxosporean sequence was consistently obtained from $O$. orientalis - infected herring and sprat, and identified with that parasite (see Karlsbakk and Køie 2011)

Careful examination of a sprat individual, which was PCR positive for the parvicapsulid found in $H$. norvegicus, led to the discovery of the minute myxospores of Parvicapsulidae gen. sp. Subsequently, other clupeid specimens found infected with this parasite by microscopy were found PCR positive for the H. norvegicus myxosporean. In the large numbers of clupeids examined, there was no evidence for additional myxosporean infections in the kidneys.

The present results suggest a high degree of intraspecific variation in the SSU rDNA of Parvicapsulidae gen. sp., which mostly can be allocated to two genotypes (B and S). The ten sequences from sprat are of type B, the three from herring are of type S. The occurrence of these genotypes in their respective host species significantly depart from random (Fisher's exact test, $\mathrm{P}<0.01$ ). The sequences from $H$. norvegicus show either $\mathrm{B}$ or $\mathrm{S}$ signal or a mixed $\mathrm{B} / \mathrm{S}$ signal.

These observations suggest that the tetractinomyxon spores in $H$. norvegicus represent a myxosporean infecting herring and sprat. The only candidate is the myxosporean found herein producing minute spores in the kidney. While unsuitable fish hosts may be PCR positive for a myxosporean species following exposure to actinosporeans (see Holzer et al. 2013), clupeids were the only species found infected with Parvicapsulidae gen. sp. of the fish species common in Øresund. These clupeid hosts have been also found infected over a large geographic area, during different times of the year, and infections revealed by PCR and sequencing are associated with a particular type of myxospores. Indeed, each clupeid species is infected with a characteristic genotype of the myxosporean. Hence the proposed two-host cycle is well supported (Fig. 3).

Observed divergence between the $\mathrm{B}$ and $\mathrm{S}$ type sequences is at $0.8 \%$, and these genotypes are significantly associated with host-species. These observations suggest that these clupeids are infected with separate strains or possibly sibling species of Parvicapsulidae gen. sp. However, morphological differences were not apparent between the minute myxospores found in sprat and herring, or between actinospores of the $\mathrm{B}$ and $\mathrm{S}$ genotypes from $H$. norvegicus. This polychaete is obviously host to both the types that infect sprat and herring, but in one of the four examined worms a mixed B/S signal was observed. We interpret this as a mixed infection with the $\mathrm{B}$ and $\mathrm{S}$ types. The occurrence of such mixed infections in the annelid host without evidence for parasite hybridization may be taken as support for a status of independent species for the sprat and herring parvicapsulids. Since the vertebrate hosts are now known, these aspects may be examined experimentally in $H$. norvegicus. 
The closest relative of the parvicapsulid reported here is Parvicapsula minibicornis. Interestingly, in that species, there is also evidence for fish-host species associated genotypes of the parasite, particularly clear in coho salmon Oncorhynchus kisutch (Walbaum) (Atkinson et al. 2011). The divergence between P. minibicornis SSU rDNA genotypes was found to be $0.1-1.1 \%$. In the only other myxosporean found in the urinary system of herring and sprat, $O$. orientalis, a possible host-related sequence divergence was also noted (Karlsbakk and Køie 2011), but more sequences are needed.

Phylogenetic analyses place Parvicapsulidae gen. sp. in a well supported clade together with $P$. minibicornis, Parvicapsula sp. genotype X and Sphaerospora testicularis Sitjà-Bobadilla et Alvarez-Pellitero, 1990. The Parvicapsula sp. genotype X sequence was obtained from water samples and polychaete infections in the western USA, and its fish host and myxospores are unknown (Atkinson et al. 2011). However, the three known species show symmetrical spores, which set them apart from most other parvicapsulids (i.e. Parvicapsula spp.).

P. minibicornis, P. pseudobranchicola and S. testicularis have been found histozoic at other sites than the typical sites in kidney, pseudobranch and testes, respectively (Sitjà-Bobadilla and Alvarez-Pellitero 1990, Sterud et al. 2003, Bradford et al. 2010). The possibility that Parvicapsulidae gen. sp. may infect other sites than the kidney in herring and sprat deserves further study, because we found few myxospores in our kidney samples.

The minute spores of Parvicapsulidae gen. sp. can be distinguished from all described species by the small size and by morphology. It mostly resembles species of Gadimyxa Køie, Karlsbakk et Nylund, 2007, but it apparently has not two morphological spore forms. Sequence comparisons and phylogenetic analysis show that Gadimyxa spp. and Parvicapsulidae gen. sp. are not closely related.

Parvicapsulidae gen. sp. appears to represent a new species of a new genus in the Parvicapsulidae, most closely related to $P$. minibicornis according to the SSU rDNA sequences. However, we refrain from erecting a new genus and species since the morphology, development and microhabitat of the novel parasite are insufficiently known.

Myxospores were found twice in $C$. harengus (prevalence $2 \% ; \mathrm{N}=100)$ and three times in $S$. sprattus $(1.5 \%$; $\mathrm{N}=200$ ) from Øresund, Denmark using microscopy. However, prevalence is probably much higher because spores may have been overlooked. All the clupeids from northern Norway examined by PCR were positive for the parasite $(\mathrm{N}=8)$, suggesting a high prevalence of infection there. The prevalence of the actinosporean developmental stages (Køie 2002) in H. norvegicus varied between 3 and $8 \%$ (about 50 specimens examined each year).

The present observations represent the sixth marine myxozoan for which both the polychaete and fish hosts are known (Køie et al. 2004, 2007, 2008, Rangel et al. 2009, Karlsbakk and Køie 2012). When these hosts are known, experimental studies may be performed in order to reveal details of the life cycles. Experimentally infected clupeids would ease the study of the very small myxospores and the description of this enigmatic myxosporean.

Acknowledgements. Dr. Siri Vike (University of Bergen) is thanked for providing sprat from Hardanger. The present study was supported by the Norwegian Biodiversity Information Centre Project no. 70184219.

\section{REFERENCES}

Atkinson S.D., Jones S.R.M., Adlard R.D., Bartholomew J.L. 2011: Geographical and host distribution patterns of Parvicapsula minibicornis (Myxozoa) small subunit ribosomal RNA genetic types. Parasitology 138: 969-977.

Bartošová P., Freeman M.A., Yokoyama H, Caffara M., FiaLA I. 2011: Phylogenetic position of Sphaerospora testicularis and Latyspora scomberomori n. gen. n. sp. (Myxozoa) within the marine urinary clade. Parasitology 138: 381-393.

Bradford M.J., Lovy J., Patterson D.A., Speare D.J., Bennett W.R., Stobbart A.R., Tovey C.P. 2010: Parvicapsula minibicornis infections in gill and kidney and the premature mortality of adult sockeye salmon (Oncorhynchus nerka) from Cultus Lake, British Columbia. Can. J. Fish. Aquat. Sci. 67: 673-683.

Fiala I. 2006: The phylogeny of Myxosporea (Myxozoa) based on small subunit ribosomal RNA gene analysis. Int. J. Parasitol. 36: $1521-1534$

Holzer A.S., Bartošová P., Pecková H., Tyml T., Atkinson S., Bartholomew J., Sipos D., Eszterbauer E., Dyková I. 2013: 'Who's who' in renal sphaerosporids (Bivalvulida: Myxozoa) from common carp, Prussian carp and goldfish - molecular identification of cryptic species, blood stages and new members of Sphaerospora sensu stricto. Parasitology 40: 46-60.

Holzer A.S., Wootten R., Sommerville C. 2010: Zschokkella hildae Auerbach, 1910: phylogenetic position, morphology, and location in cultured Atlantic cod. Parasitol. Int. 59: 133-140.

Karlsbakx E., KøIE M. 2011: Morphology and SSU rDNA sequences of Ortholinea orientalis (Shul'man and Shul'man-Albova, 1953) (Myxozoa, Ortholineidae) from Clupea harengus and Sprattus sprattus (Clupeidae) from Denmark. Parasitol. Res. 109: 139-145.

Karlsbakk E., Køie M. 2012: The marine myxosporean Sigmomyxa sphaerica (Thélohan, 1895) gen. n., comb. n. (syn. Myxidium sphaericum) from garfish (Belone belone (L.)) uses the polychaete Nereis pelagica L. as invertebrate host. Parasitol. Res. 110: 211-218.

KøIЕ M. 2002. Spirorbid and serpulid polychaetes are candidates as invertebrate hosts for Myxozoa. Folia Parasitol. 49: 160-162.

Køie M., Karlsbakk E., Nylund A. 2007: A new genus Gadimyxa with three new species (Myxozoa, Parvicapsulidae) parasitic in marine fish (Gadidae) and the two-host life cycle of Gadimyxa atlantica n. sp. J. Parasitol. 93: 1459-1467. 
Køie, M., Karlsbakk E., Nylund A. 2008: The marine herring myxozoan Ceratomyxa auerbachi (Myxozoa, Ceratomyxidae) uses Chone infundibuliformis (Annelida, Polychaeta, Sabellariidae) as invertebrate host. Folia Parasitol. 55: 100-104.

Køie M., Whipps C.M., Kent M.L. 2004: Ellipsomyxa gobii (Myxozoa: Ceratomyxidae) in the common goby Pomatoschistus microps (Teleostei: Gobiidae) uses Nereis spp. (Annelida: Polychaeta) as invertebrate host. Folia Parasitol. 51: 14-18.

Nylund A., Karlsbakk E., Saether P.A., Koren C., Larsen T., Brøderud B.D., Høstlund C., Fjellsøy K.R., Lervik K., Rosnes L. 2005: Parvicapsula pseudobranchicola (Myxosporea) in farmed Atlantic salmon Salmo salar: tissue distribution, diagnosis and phylogeny. Dis. Aquatic. Org. 63: 197-204.

Rangel L.F., Cech G., Székely C., Santos M.J. 2011. A new actinospore type Unicapsulactinomyxon (Myxozoa), infecting the marine polychaete, Diopatra neapolitana (Polychaeta: Onuphidae) in the Aveiro Estuary (Portugal). Parasitology 138: 698-712.

Rangel L.F., Santos M.J., Cech G., Székely C. 2009: Morphology, molecular data and development of Zschokkella mugilis (Myxosporea, Bivalvulida) in a polychaete alternate host, Nereis diversicolor. J. Parasitol. 95: 561-569.
Ronquist, F., Huelsenbeck J.P. 2003: MrBayes 3: Bayesian phylogenetic inference under mixed models. Bioinformatics 19: $1572-1574$.

Sitjà-Bobadilla A., Alvarez-Pellitero P. 1990: Sphaerospora testicularis sp. nov. (Myxosporea: Sphaerosporidae) in wild and cultured sea bass, Dicentrarchus labrax (L.), from the Spanish Mediterranean area. J. Fish Dis. 13: 193-203.

Sterud E., Simolin P., Kvellestad A. 2003: Infection by Parvicapsula sp. (Myxozoa) is associated with mortality in seacaged Atlantic salmon Salmo salar in northern Norway. Dis. Aquat. Org. 54: 259-263.

Tamura K., Peterson D., Peterson N., Stecher G., Nei M., Kumar S. 2011: MEGA5: Molecular Evolutionary Genetics Analysis using maximum likelihood, evolutionary distance, and maximum parsimony methods. Mol. Biol. Evol. 28: 27312739.

Yokoyama H., Grabner D., Shirakashi S. 2012: Transmission biology of the Myxozoa. In: E.D. Carvalho, G.S. David and R.J. Silva (Eds.), Health and Environment in Aquaculture, pp. 3-42. InTech, Rijeka (http://www.intechopen.com/books/ health-and-environment-in-aquaculture)

Accepted 19 November 2012 